\title{
Pengaruh Model Pembelajaran Kooperatif Tipe NHT (Numbered Head Together) Terhadap Hasil Belajar Matematika
}

\author{
Putu Tia Vivi Muliandari* \\ Jurusan Pendidikan Guru Sekolah Dasar, Universitas Pendidikan Ganesha, Indonesia
}

\section{A R T I CLEINFO \\ Article history: \\ Received 18 February 2019 \\ Received in revised form 20 March 2019 \\ Accepted 20 April 2019 \\ Available online 20 May 2019}

Kata Kunci:

NHT, hasil belajar

Matematika

Keywords:

NHT, learning result of

Mathematics.

\begin{abstract}
A B S T R A K
Penelitian ini bertujuan untuk mengetahui pengaruh hasil belajar Matematika antara siswa yang dibelajarkan dengan menggunakan model pembelajaran kooperatif tipe NHT dan siswa yang dibelajarkan tanpa menggunakan model pembelajaran kooperatif tipe NHT di kelas V SD gugus IV Sukasada Kecamatan Sukasada, Kabupaten Buleleng. Populasi dalam penelitian ini adalah siswa kelas $\mathrm{V}$ SD di Gugus IV Sukasada Kecamatan Sukasada, Kabupaten Buleleng tahun pelajaran 2017/2018. Sampel penelitian adalah siswa kelas V SD No 4 Sukasada sebagai kelas eksperimen dan siswa kelas V SD No 3 Ambengan sebagai kelas kontrol. Pengumpulan data penelitian ini menggunakan metode observasi dan instrumen tes objektif hasil belajar. Teknik analisis yang digunakan adalah analisis deskriptif dan uji-t. Berdasarkan analisis data dengan uji-t, diperoleh nilai thitung sebesar 3,3 lebih besar dari nilai ttabel sebesar 2,021 dengan taraf signifikansi $5 \%$. Perbandingan hasil perhitungan rata-rata nilai hasil belajar Matematika siswa yang dibelajarkan menggunakan model pembelajaran kooperatif tipe NHT 21,1 sedangkan siswa yang dibelajarkan tanpa menggunakan model pembelajaran kooperatif tipe NHT 18,95. Ini berarti bahwa penggunaan model pembelajaran kooperatif tipe NHT berpengaruh terhadap hasil belajar Matematika siswa kelas V SD di gugus IV Sukasada Kecamatan Sukasada, Kabupaten Buleleng tahun ajaran 2017/2018.
\end{abstract}

\section{A B S T R A C T}

The purpose of this research was to know the effect of the learning result of Mathematics subject between the students that by using cooperative learning model type NHT and students who were taught without using cooperative learning model type $\mathrm{NHT}$ in which the students were fifth-grade of elementary school cluster IV in Sukasada sub-District, Buleleng District. The population in this study were the students of fifth-grade of an elementary school in Sukasada, Buleleng academic year 2017/2018. The sample of the research is the students of fifth-grade SD No 4 Sukasada as experimental class and fifth-grade of SD No 3 Ambengan as the control class. The data collection of this research used observation method and objective test instrument of learning result. The analysis technique used was descriptive analysis and t-test. The collected data analysis with t-test, obtained thitung of 3,3 is bigger than ttabel value equal to 2,021 with $5 \%$ significance level. Comparison of the calculation of the average value of learning Mathematics of students taught using cooperative learning model type NHT 21,1 while students are taught without using cooperative learning model type NHT 18,95. This means the use cooperative learning model of type NHT effect the learning result of Mathematics for students fifth-grade elementary school cluster IV Sukasada sub-District., Buleleng District for the academic year 2017/2018. 


\section{Pendahuluan}

Setiap anak memerlukan pendidikan sebagai bekal untuk menghadapi persaingan global yang semakin ketat. Pendidikan memberikan peluang bagi anak untuk bersaing dan mengembangkan potensi dirinya. Pada jenjang pendidikan dasar, siswa mempelajari lima mata pelajaran pokok seperti Bahasa indonesia, Matematika, IPA, IPS, dan PKn. Materi-materi pada berbagai mata pelajaran bersumber dari lingkungan sekitar kita. Proses pembelajaran akan lebih berhasil apabila disesuaikan dengan peringkat perkembangan kognitif siswa. Siswa hendaknya banyak diberi kesempatan untuk melakukan pemecahan masalah, yang ditunjang oleh interaksi dengan teman sebaya, dan dibantu oleh pertanyaan tilikan dari guru. Selain itu, guru hendaknya memberikan rangsangan kepada siswa agar mau berinteraksi dengan lingkungan dan secara aktif mencari serta menemukan berbagai hal di lingkungannya agar bisa mendapatkan hasil belajar yang lebih baik. Seperti halnya pada pelajaran Matematika yang mempelajari bilangan terutama pada rumus yang akan di pakai untuk menghitung bilangan tersebut.

Matematika seharusnya menjadi salah satu mata pelajaran yang menyenangkan dan digemari oleh siswa. Namun, bagi sebagian besar siswa, Matematika merupakan mata pelajaran yang dianggap paling sulit, paling membosankan dan tak jarang juga dianggap sebagai mata pelajaran yang paling menakutkan. Kondisi ini mengakibatkan mata pelajaran Matematika tidak disenangi, tidak diperdulikan dan bahkan diabaikan. Berbagai upaya telah dilakukan untuk meningkatkan mutu pendidikan, mengingat begitu pentingnya pendidikan bagi peningkatan kualitas SDM. Berbagai upaya untuk meningkatkan mutu pendidikan ini diharapkan nantinya bermuara pada meningkatnya hasil belajar siswa khususnya dalam mata pelajaran Matematika.

Berdasarkan hasil observasi yang dilakukan saat guru memberikan materi pembelajaran ditemukan fakta bahwa: (1) guru lebih sering menggunakan soal-soal yang terdapat pada buku dan LKS karena guru merasa soal yang terdapat pada buku dan LKS sudah sesuai dengan materi, (2) guru kurang memberikan motivasi belajar pada siswa karena siswa dalam pembelajaran di kelas hanya sebagai pendengar yang mengakibatkan siswa lekas merasa bosan dalam mengikuti pembelajaran, (3) proses pembelajaran masih berpusat pada guru (teacher centered) karena guru masih merasa kesulitan untuk membuat siswa agar mau berperan aktif dalam proses pembelajaran, (4) pembelajaran masih didominasi dengan metode ceramah karena guru merasa belum benar-benar mengajar jika tidak menjelaskan secara panjang lebar (5) keterampilan menguraikan jawaban siswa rendah yang berujung pada ketidakmampuan mengerjakan soal uraian. Hal ini berdampak pada rendahnya nilai Matematika.

Hasil observasi tersebut didukung oleh hasil wawancara yang dilakukan dengan guru Matematika kelas V di SD Gugus IV Sukasada. Berdasarkan wawancara yang dilakukan diperoleh informasi bahwa: (1) siswa masih sangat lemah saat mengerjakan soal Matematika dalam bentuk uraian karena pengetahuan yang dimiliki siswa masih bersifat hapalan, (2) siswa tidak mampu menguraikan secara sistematis jawaban mereka meskipun memperoleh hasil akhir yang benar, (3) guru lebih banyak memberikan jenis soal tertutup karena guru masih merasa kesulitan dalam membuat soal terbuka dan (4) rata-rata nilai Matematika siswa kelas V di SD Gugus IV Sukasada masih rendah.

Berdasarkan permasalah atau fenomena tersebut, maka perlu diterapkan suatu sistem pembelajaran yang melibatkan peran siswa secara aktif dalam kegiatan belajar mengajar, guna meningkatkan prestasi belajar matematika disetiap jenjang pendidikan. Salah satu model pembelajaran yang melibatkan peran siswa secara aktif adalah model pembelajaran kooperatif. Model pembelajaran kooperatif sangat cocok diterapkan pada pembelajaran matematika karena dalam mempelajari matematika tidak cukup hanya mengetahui dan menghafal konsep-konsep matematika tetapi juga dibutuhkan suatu pemahaman serta kemampuan menyelesaikan persoalan matematika dengan baik dan benar. Melalui model pembelajaran ini siswa dapat mengemukakan pemikirannya, saling bertukar pendapat, saling bekerja sama jika ada teman dalam kelompoknya yang mengalami kesulitan. Hal ini dapat meningkatkan hasil belajar siswa untuk mengkaji dan menguasai materi pelajaran matematika sehingga nantinya akan mendapatkan hasil belajar dengan prestasi belajar matematika siswa yang baik.

Melihat penguasaan siswa terhadap materi pelajaran Matematika maka dalam penelitian ini model pembelajaran yang dipilih adalah model pembelajaran kooperatif tipe NHT (Numbered Heads Together) karena pada model ini siswa menempati posisi sangat dominan dalam proses pembelajaran dan terjadinya kerja sama dalam kelompok dengan ciri utamanya adanya penomoran sehingga semua siswa berusaha untuk memahami setiap materi yang diajarkan dan bertanggung jawab atas nomor anggotanya masing - masing. Numbered Head Together (NHT) dapat membantu siswa memahami dan juga dapat menguasai konsep pembelajaran Matematika, meningkatkan kemampuan kerja sama antar siswa, dan meningkatkan kemampuan berpikir kritis. Pelibatan siswa secara kolaboratif dalam kelompok untuk mencapai tujuan bersama ini memungkinkan Numbered Heads Together (NHT) dapat meningkatkan hasil 
belajar siswa khususnya hasil belajar kognitif.menurut Wati (2013) pada pembelajaran kooperatif tipe NHT, siswa dalam kelas dikelompokkan secara heterogen

Trianto (2009:58) menyatakan, "Bagi siswa yang hasil belajarnya rendah, Numbered Head Together (NHT) mampu meningkatkan kepercayaan diri pada siswa, memperbaiki tingkat kehadiran siswa dalam proses belajar mengajar, mengurangi perilaku yang mengganggu siswa lain, mengurangi konflik antar pribadi, memperoleh pemahaman yang lebih mendalam, meningkatkan semangat kerjasama dalam kelompok, memberikan kesempatan kepada siswa untuksaling membagi ide-ide dan mendiskusikan jawaban yang paling tepat, serta memperoleh hasil belajar yang lebih baik". Penelitian oleh Ridwanthi (2013) menyatakan bahwa model pembelajaran kooperatif tipe NHT berbantuan media question cards berpengaruh terhadap hasil belajar matematika siswa

Uraian tersebut, maka dilakukan penelitian yang berjudul: "Pengaruh Model Pembelajaran Kooperatif Tipe NHT (Numbered Head Together) Terhadap Hasil Belajar Matematika Pada Siswa Kelas V gugus IV Sukasada Kecamatan Sukasada Tahun Ajaran 2017 / 2018”. Permasalahan yang dapat dirumuskan sebagai berikut. Apakah ada pengaruh terhadap hasil belajar Matematika antara kelompok siswa yang belajar dengan menggunakan model pembelajaran kooperatif tipe NHT dan kelompok siswa yang belajar tidak menggunakan model pembelajaran kooperatif tipe NHT?

Penelitian ini bertujuan untuk mengetahui pengaruh yang signifikan hasil belajar Matematika antara kelompok siswa yang belajar dengan menggunakan model pembelajaran kooperatif tipe NHT dan kelompok siswa yang belajar tidak menggunakan model pembelajaran kooperatif tipe NHT pada siswa kelas V di Gugus IV Sukasada Kecamatan Sukasada.

\section{Metode}

Penelitian ini dilaksanakan di SD Gugus IV Sukasada Kecamatan Sukasada. Penelitian ini dirancang pada kelas V semester genap tahun pelajaran 2017/2018. Dalam penelitian ini unit eksperimennya berupa kelas, sehingga penelitian yang digunakan adalah penelitian semu. Dalam eksperimen semu, penempatan subjek kedalam kelompok yang dibandingkan tidak dilakukan secara acak. Individu subjek sudah ada dalam kelompok yang dibandingkan sebelum diadakannya penelitian.

Populasi dalam penelitian ini adalah semua siswa kelas V SD di Gugus IV Sukasada. Banyak populasi dalam penelitian ini adalah 171 siswa yang tersebar kedalam 8 kelas V di Gugus IV Sukasada, yaitu kelas V SD No 1 Sukasada, kelas V SD No 2 Sukasada, kelas V SD No 3 Sukasada, kelas V SD No 4 Sukasada, kelas V SD No 5 Sukasada, kelas V SD No 1 Ambengan, kelas V SD No 2 Ambengan, dan kelas V SD No 3 Ambengan

Tabel 1. Distribusi Populasi Peneltian

\begin{tabular}{ccc}
\hline No & Nama SD & Jumlah siswa (orang) \\
1 & SD No 1 Sukasada & 20 \\
2 & SD No 2 Sukasada & 29 \\
3 & SD No 3 Sukasada & 32 \\
4 & SD No 4 Sukasada & 20 \\
5 & SD No 5 Sukasada & 10 \\
6 & SD No 1 Ambengan & 14 \\
7 & SD No 2 Ambengan & 26 \\
8 & SD No 3 Ambengan & 20 \\
\hline
\end{tabular}

Sebelum menentukan sampel yang akan diambil dalam penelitian ini, terlebih dahulu harus dilakukan uji kesetaraan populasi. Dalam menghitung kesetaraan kelompok sampel digunakan rumus Analisis Varians Satu Jalur (ANAVA klasifikasi tunggal).

Berdasarkan hasil perhitungan dengan menggunakan analisis varian (ANAVA) pada taraf signifikansi 5\%, diperoleh nilai Fhit sebesar 0,78 sedangkan nilai Ftab sebesar 1,99. Dengan demikian, Fhit < Ftab, sehingga H0 diterima. Dari pernyataan tersebut dapat ditarik simpulan bahwa H0 yang menyatakan tidak terdapat pengaruh yang signifikan antara ranah kognitif siswa Kelas V di SD Gugus IV Sukasada Kecamatan Sukasada diterima. Jadi dapat diinterpretasikan bahwa sampel setara.

Teknik pengambilan sampel yang digunakan dalam penelitian ini adalah teknik cluster random sampling. Sampel yang dirandom dalam penelitian ini adalah kelas karena dalam eksperimen tidak memungkinkan untuk mengubah kelas yang ada. Kelas yang akan dirandom merupakan kelas dalam jenjang yang sama. Kelas - kelas tersebut adalah kelas V dari masing-masing sekolah dasar di Gugus IV Sukasada. 
Melalui random sampling, ditetapkan kelompok siswa kelas V di SD No 4 Sukasada yang berjumlah 20 orang sebagai kelompok eksperimen yang diberi perlakuan berupa model pembelajaran NHT dan kelompok siswa kelas V di SD No 3 Ambengan yang berjumlah 20 orang sebagai kelompok kontrol yang diberi perlakuan berupa pembelajaran tidak menggunakan model NHT.

Data yang dikumpulkan pada penelitian ini adalah data hasil belajar siswa. Data untuk hasil belajar siswa dikumpulkan dengan menggunakan tes objektif hasil belajar yang diberikan kepada siswa pada akhir pembelajaran. Tes hasil belajar ini terdiri atas 28 butir soal. Data hasil belajar dikumpulkan dengan menggunakan tes objektif setelah diberikan perlakuan. Keseluruhan data yang diambil kepada siswa dari seluruh sampel penelitian, artinya baik untuk kelompok siswa yang dibelajarkan menggunakan model kooperatif tipe NHT maupun kelompok siswa yang dibelajarkan tanpa menggunakan model kooperatif tipe NHT.

Sebelum digunakan dalam penelitian, instrumen penelitian terlebih dahulu dilakukan uji coba atau validitas. Uji coba atau validitas instrumen dilakukan agar diperoleh gambaran kelayakan dari instrumen tersebut untuk digunakan dalam penelitian. Uji coba yang dilakukan bergantung pada jenis instrumen yang digunakan. Yang meliputi uji validitas isi tes objektif hasil belajar, uji validitas butir soal tes objektif hasil belajar, dan uji reliabilitas tes objektif hasil belajar.

Teknik analisi data yang digunakan yaitu ada dua teknik analisi statistik deskriptif dan statistik inferensial dalam hal ini yaitu analisi varians (ANAVA) satu jalur. Analisis deskriptif dilakukan untuk mengetahui tinggi rendahnya kualitas dari dua variabel, yaitu penggunaan model pembelajaran kooperatif tipe NHT dan hasil belajar. Untuk menentukan kualitas variabel - variabel tersebut, skor rata - rata (mean) tiap-tiap variabel dikonversikan dengan menggunakan kriteria rata - rata ideal dan Standar deviasi (SD). Adapun analisis statistik inferensial dalam penelitian ini adalah uji-t independet (tidak berkorelasi) dengan rumus polled varians. Sebelum menguji hipotesis penelitian, maka dilakukan uji prasarat yang meliputi uji normalitas dengan uji chi-Squre dan uji homogenitas varians dengan uji-F

\section{Hasil dan Pembahasan}

Untuk memperoleh gambaran tentang hasil belajar Matematika, data dianalisis dengan analisis deskriptif agar dapat diketahui Mean (M), median (Md), Modus (Mo), dan standar deviasi. Rangkuman hasil analisis deskriptif disajikan pada Tabel 2.

Tabel 2. Rekapitulasi Hasil Perhitungan Hasil belajar Matematika

\begin{tabular}{lcc}
\hline \multicolumn{1}{c}{ Statistik Deskriptif } & Kelompok Eksperimen & Kelompok Kontrol \\
Mean (M) & 21,1 & 18,95 \\
Median (Md) & 21,79 & 16,3 \\
Modus (Mo) & 20,92 & 15,7 \\
Varians & 15,04 & 25,62 \\
Standar Deviasi & 3,88 & 5,06 \\
Skor Minimum & 14 & 13 \\
Skor Maximum & 28 & 28 \\
Rentangan & 15 & 16 \\
\hline
\end{tabular}

Berdasarkan Tabel 2 dapat dilihat bahwa rata - rata nilai hasil belajar kelompok eksperimen yang dibelajarkan dengan menggunakan model pembelajaran kooperatif tipe NHT lebih tinggi dari rata - rata nilai hasil belajar siswa kelompok kontrol. Data kelas eksperimen dan kontrol disajikan pada grafik berikut. 


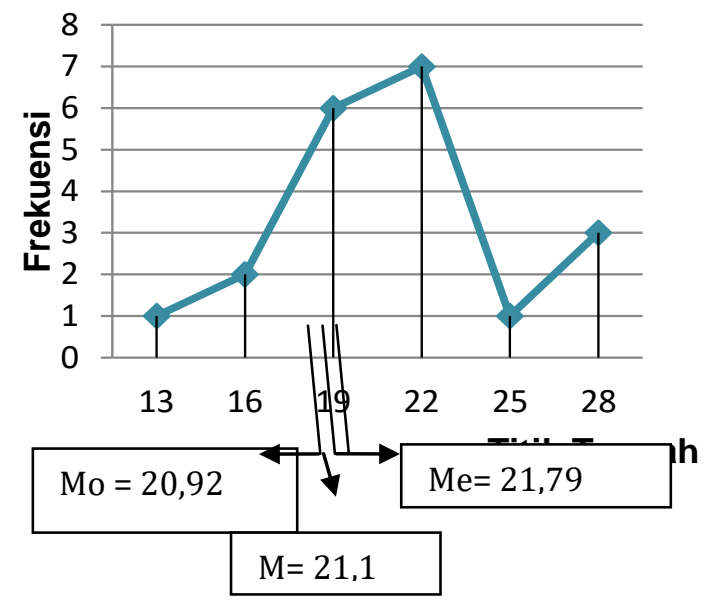

Gambar 1. Kurva Poligon Data Hasil Belajar Matematika Kelompok Eksperimen

Berdasarkan Gambar 1 kurva poligon data hasil belajar Matematika kelompok eksperimen, dapat diketahui bahwa median lebih besar dari mean dan mean lebih besar dari modus (Me $>$ M $>$ Mo). Dengan kata lain, kurva pada Gambar 1 adalah kurva juling negatif. Artinya, sebagian besar skor cenderung tinggi. Untuk menentukan tinggi rendahnya hasil belajar Matematika pada kelas eksperimen, digunakan kriteria penilaian skala lima. Adapun penentuan tinggi rendahnya hasil belajar Matematika kelompok eksperimen menggunakan pedoman konversi skala lima.

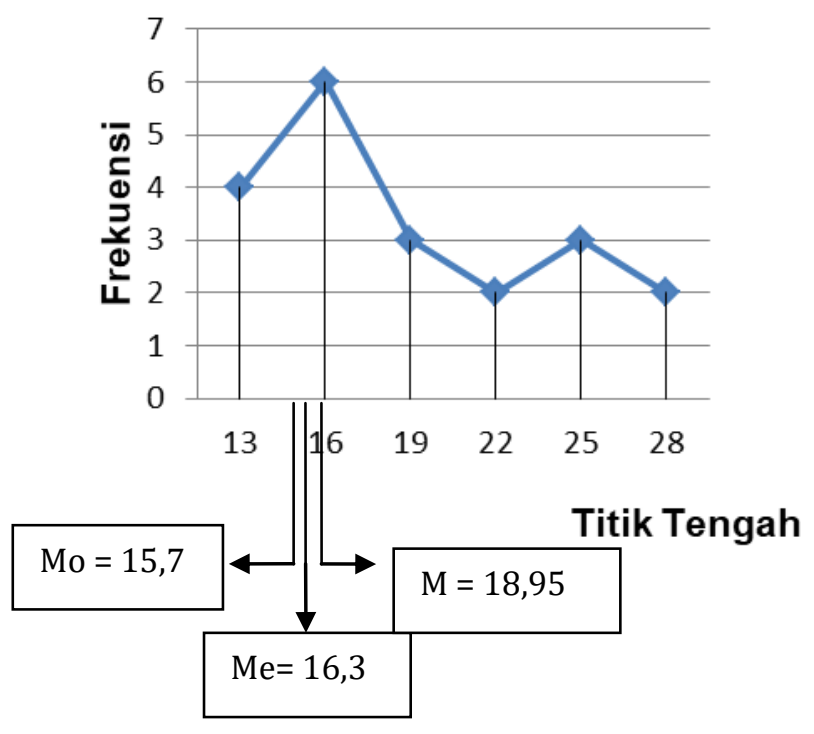

Gambar 2. Kurva Poligon Data Hasil Belajar Matematika Kelompok Kontrol

Berdasarkan Gambar 2 kurva poligon data hasil belajar Matematika kelompok kontrol, dapat diketahui bahwa mean lebih besar dari median dan median lebih besar dari modus $(\mathrm{M}>\mathrm{Me}>\mathrm{Mo})$. Dengan kata lain, kurva pada Gambar 2 adalah kurva juling positif. Artinya, sebagian besar skor cenderung rendah. Untuk menentukan tinggi rendahnya hasil belajar Matematika pada kelas kontrol, digunakan kriteria penilaian skala lima. Adapun penentuan tinggi rendahnya hasil belajar Matematika kelompok kontrol dengan kualifikasi menggunakan pedoman konversi skala lima.

Tabel 3. Kategori Data Hasil Belajar Matematika Kelompok Eksperimen dan Kontrol

\begin{tabular}{cc}
\hline Rentang Skor & Kategori \\
\hline $20,99 \leq X \leq 27,98$ & Sangat tinggi \\
$16,33 \leq X \leq 20,99$ & Tinggi \\
$12,33 \leq X \leq 16,33$ & Sedang \\
\hline
\end{tabular}


$7,01 \leq \mathrm{X} \leq 12,33$

$0,02 \leq X \leq 7,01$
Rendah

Sangat rendah

Berdasarkan Tabel 3. rata-rata (X) skor hasil belajar pada mata pelajaran Matematika kelompok eksperimen terletak pada kategori sangat tinggi yaitu 21,1 yang berada pada rentangan $20,99 \leq X \leq$ 27,98 dan rata-rata (X) skor hasil belajar pada mata pelajaran Matematika kelompok kontrol terletak pada kategori tinggi yaitu 18,95 yang berada pada rentangan $16,33 \leq X \leq 20,99$

Sebelum melakukan uji hipotesis terlebih dahulu dilakukan uji prasyarat yang meliputi uji normalitas dilakukan untuk membuktikan bahwa frekuensi data penelitian benar-benar berdistribusi normal. Hasil uji normalitas sebaran data didapatkan $\chi^{2}$ hit hasil post-test kelompok eksperimen adalah 4,72 dan $\chi^{2}$ tab dengan taraf signifikansi $5 \%$ dan db $=3$ adalah 7,81. Hal ini berarti, $\chi^{2}$ hit hasil post-test kelompok eksperimen lebih kecil dari $\chi_{\text {tab }}^{2}\left(\chi^{2}{ }_{h i t}<\chi^{2}{ }_{t a b}\right)$, sehingga data hasil post-test kelompok eksperimen berdistribusi normal. $\chi^{2}{ }_{\text {hit }}$ hasil post-test kelompok kontrol adalah 4,75 dan $\chi^{2}$ tab dengan taraf signifikansi $5 \%$ dan $\mathrm{db}=3$ adalah 7,81. Hal ini berarti, $\chi^{2}$ hit hasil post-test kelompok kontrol lebih kecil dari $\chi_{\text {tab }}^{2}\left(\chi_{\text {hit }}^{2}<\chi_{\text {tab }}^{2}\right.$ ), sehingga data hasil post-test kelompok kontrol berdistribusi normal.

Uji homogenitas varians dilakukan terhadap varians pasangan antar kelompok eksperimen dan kontrol. Uji yang digunakan adalah uji $\mathrm{F}$ dengan kriteria data homogen jika $\mathrm{F}_{\text {hitung }}<\mathrm{F}_{\text {tabel }}$. Berdasarkan hasil perhitungan uji homogenitas didapatkan $\mathrm{F}_{\text {hit }}$ hasil belajar mata pelajaran Matematika pada kelompok eksperimen dan kontrol adalah 1,70 , sedangkan $F_{\text {tab }}$ pada $d_{b_{\text {pembilang }}}=20, b_{\text {penyebut }}=20$, pada taraf signifikansi 5\% adalah 2.12. Hal ini berarti, varians data hasil belajar mata pelajaran Matematika pada kelompok eksperimen dan kontrol adalah homogen.

Berdasarkan hasil analisis uji prasyarat hipotesis, diperoleh bahwa data hasil belajar Matematika siswa kelompok eksperimen dan kontrol adalah normal dan homogen, sehingga pengujian hipotesis penelitian dengan uji-t dapat dilakukan.

Uji hipotesis dilakukan dengan menggunakan statistik uji-t dengan rumus polled varians. Kriteria pengujian adalah tolak $\mathrm{H}_{0}$ jika $\mathrm{t}_{\text {hitung }}>\mathrm{t}_{\text {tabel, }}$ dimana $\mathrm{t}_{\text {tabel }}$ diperoleh dari tabel distribusi $t$ pada taraf signifikansi $5 \%$ dengan derajat kebebasan $d b=n 1+n 2-2$.

Tabel 4. Hasil Penghitungan Uji-t

\begin{tabular}{ccccccc}
\hline Kelompok & $\mathbf{N}$ & $\mathbf{D b}$ & $\mathbf{M e a n}\left(\mathbf{(}^{-}\right)$ & $\mathbf{s}^{2}$ & $\mathbf{t}_{\text {hitung }}$ & $\mathbf{t}_{\text {tabel }}$ \\
\hline Eksperimen & 20 & \multirow{2}{*}{38} & $\begin{array}{c}21,1 \\
18,95\end{array}$ & $\begin{array}{c}15,04 \\
25,62\end{array}$ & \multirow{2}{*}{3,3} & \multirow{2}{*}{2,021} \\
Kontrol & 20 & & & \\
\hline
\end{tabular}

Berdasarkan hasil penghitungan tersebut, dapat diketahui $t_{\text {hitung }}=3,3$ dan $t_{\text {tabel }}=2,021$ untuk $\mathrm{db}=$ 38 pada taraf signifikansi $5 \%$. Berdasarkan kriteria pengujian, karena $t_{\text {hitung }}>t_{\text {tabel }}$ maka $\mathrm{H}_{0}$ ditolak dan $\mathrm{H}_{1}$ diterima. Artinya, terdapat pengaruh hasil belajar pada mata pelajaran Matematika antara kelompok siswa yang dibelajarkan menggunakan model pembelajaran kooperatif tipe NHT dan kelompok siswa yang dibelajarkan tidak menggunakan model pembelajaran kooperatif tipe NHT pada siswa kelas V di SD Gugus IV Sukasada Kecamatan Sukasada Kabupaten Buleleng Tahun Pelajaran 2017/2018.

Pada penelitian ini, yang diteliti adalah pembelajaran menggunakan model pembelajaran kooperatif tipe NHT dengan pembelajaran tanpa menggunakan model pembelajaran kooperatif tipe NHT terhadap hasil belajar Matematika. Hasil uji hipotesis menunjukkan bahwa $\mathrm{H}_{0}$ ditolak dan $\mathrm{H}_{1}$ diterima. Hasil analisis data diperoleh dari rata-rata skor hasil belajar siswa dan hasil uji-t. Rata-rata skor hasil belajar siswa yang dibelajarkan menggunakan model pembelajaran kooperatif tipe NHT adalah 21,1 dan rata-rata skor hasil belajar siswa yang dibelajarkan tanpa menggunakan model pembelajaran kooperatif tipe NHT adalah 18,95. Hal ini menunjukkan bahwa rata-rata skor hasil belajar kelompok siswa yang dibelajarkan dengan menggunakan model pembelajaran kooperatif tipe NHT lebih tinggi dibandingkan skor rata-rata kelompok siswa yang dibelajarkan tanpa menggunakan model pembelajaran kooperatif tipe NHT.

Pembelajaran menggunakan model kooperatif tipe NHT yang diterapkan pada kelas eksperimen dan pembelajaran tanpa menggunakan model kooperatif tipe NHT yang diterapkan pada kelas kontrol di kelas V Gugus IV Sukasada Kecamatan Sukasada, dalam penelitian ini menunjukkan bahwa terdapat perbedaan pada hasil belajar Matematika siswa. Perbedaan perlakuan antara proses pembelajaran yang 
menggunakan model kooperatif tipe NHT dan pembelajaran tanpa menggunakan model kooperatif tipe NHT tentunya memberikan dampak yang berbeda pula terhadap hasil belajar Matematika siswa.

Perbedaan situasi belajar pada kedua kelompok sudah mulai terlihat pada saat kedua kelompok diberikan perlakuan berupa pembelajaran dengan model NHT pada kelompok eksperimen dan tanpa menggunakan model NHT pada kelompok kontrol. Pembelajaran kelompok eksperimen berpusat pada siswa sehingga terlihat siswa lebih antusias dan aktif dalam mengikuti kegiatan pembelajaran. Hal tersebut dapat dipantau dari keaktifan siswa saat menjawab pertanyaan dan mengomunikasikan hasil pemikirannya saat proses pembelajaran berlangsung.

Penggunaan model kooperatif tipe NHT dalam pembelajaran, menjadikan siswa lebih bersemangat untuk belajar dan adanya dorongan untuk belajar lebih giat serta tidak merasa takut lagi belajar Matematika. Pada proses pelaksanaan pembelajaran dengan menggunakan model kooperatif tipe NHT ini, guru merasa bahwa siswa mengalami perubahan tingah laku dan motivasi dalam pembelajaran Matematika. Siswa menjadi lebih antusias dalam mengikuti proses pembelajaran. Selain itu, guru juga merasa lebih bertanggung jawab untuk belajar, meningkatan kreativitasnya, dan menjadikan pembelajaran yang lebih bermakna untuk siswa.

Peningkatan hasil belajar matematika siswa terjadi karena diterapkannya model pembelajaran kooperatif tipe NHT. Ketika proses pembelajaran berlangsung siswa tidak jenuh dalam pembelajaran, siswa dapat bekerjasama untuk menyatukan ide - ide yang dimiliki siswa dan siswa menjadi berani untuk mengemukakan pendapatnya di depan kelas sehingga siswa menjadi aktif dalam proses pembelajaran serta membuat siswa lebih bertanggung jawab. Sadirman (2011:97) menyatakan bahwa "Dalam kegiatan belajar, siswa harus aktif berbuat, degan kata lain bahwa dalam proses belajar sangat diperlukan adanya aktivitas".

Siswa secara langsung dapat memecahkan masalah, memahami suatu materi secara berkelompok dan saling membantu antara satu dengan yang lainnya, membuat kesimpulan serta mempresentasikan di depan kelas sebagai salah satu langkah evaluasi terhadap kegiatan pembelajaran yang telah dilakukan. Keterlibatan aktif siswa terbukti dapat meningkatkan hasil belajar dan aktivitas siswa dalam kegiatan pembelajaran. Model pembelajaran kooperatif tipe NHT berupaya menanamkan dasar-dasar berpikir ilmiah pada diri siswa karena dalam proses pembelajaran siswa lebih banyak belajar sendiri sehingga menyebabkan siswa lebih kreatif dalam memecahkan masalah

Tingkat pemahaman yang diperoleh siswa lebih besar karena siswa dilibatkan secara langsung dalam menemukan jawaban terhadap persoalan dan langsung menerapkannya melalui pengumpulan data kemudian dianalisis sehingga proses pembelajaran lebih efektif dan efisien. Siswa menganggap pembelajaran dengan menggunakan model kooperatif tipe NHT yang melibatkan siswa langsung lebih menarik dan siswa menjadi bersemangat untuk mengikuti pembelajaran. Kegiatan yang menarik akan mendorong siswa lebih mudah masuk ke dalam zona nyaman untuk belajar didalam kelas.

Selain itu, dalam pelaksanaannya model pembelajaran kooperatif tipe NHT tidak memerlukan biaya yang terlalu tinggi, karena model ini hanya memerlukan bantuan berupa ikat kepala dari karet yang berisi nomor yang dapat dibuat sendiri. Model ini juga dianggap dapat mengurangi intensitas jawaban serentak dari siswa. Temuan hasil penelitian tersebut sesuai dengan temuan Yudiastuti (2014) dan Dewi (2016) yang menunjukkan bahwa hasil penelitian dengan menggunakan model pembelajaran koopeartif tipe NHT memberikan pengaruh positif dalam meningkatkan hasil belajar siswa dibandingkan dengan pembelajaran yang tidak menggunakan model pembelajaran kooperatif tipe NHT. Hal ini disebabkan oleh penggunaan model kooperatif tipe NHT menjadikan siswa aktif selama proses pembelajaran. Kegiatan pembelajaran dengan menggunakan model kooperatif tipe NHT mengajak siswa untuk mampu mengemukakan pendapat di muka umum dan mampu bersosialiasasi dengan teman-temannya.

Selain itu, siswa akan merasa lebih senang saat belajar dan tidak akan cepat merasa bosan. Pembelajaran dengan model kooperatif tipe NHT juga membuat siswa lebih tertantang dalam belajar, karena siswa tidak akan pernah tahu kapan guru akan memanggil nomor yang ada pada kepala merekaa. Hal inilah yang memacu siswa harus lebih giat belajar agar mampu menjawab pertanyaan yang diberikan oleh gurunya. Relevansi penelitian ini adalah sama-sama meneliti tentang hasil belajar pada ranah kognitif dengan menerapkan model pembelajaran kooperatif tipe NHT.

Melalui model pembelajaran kooperatif tipe NHT ini siswa dapat leluasa dalam mengemukakan pendapat dan belajar menghargai pendapat orang lain dengan tetap mengacu pada materi dan tujuan pembelajaran sehingga dapat meningkatkan hasil belajar siswa. Menghargai pendapat orang lain sangat diperlukan didalam melakukan diskusi. Seperti yang ditemukan pada penelitian yang dilakukan, banyak kelompok yang mau mendengarkan apa yang disampaikan oleh kelompok lain walaupun jawaban kelompok tersebut belum terbukti benar. Jadi, model pembelajaran kooperatif tipe NHT lebih baik diterapkan untuk meningkatkan hasil belajar matematika siswa. 
Penelitian ini dikuatkan oleh penelitian sebelumnya yang dilakukan oleh Rika Fima Yenni (2016) menyatakan Berdasarkan hasil perhitungan menggunakan software minitab diperoleh P-value $=0,016$ pada taraf kepercayaan $95 \%(\alpha=0,05)$. Karena P-value $<\alpha$ maka tolak H0 dan terima H1. Ini berarti hasil belajar matematika siswa yang menggunakan metode NHT lebih baik dari pada hasil belajar matematika siswa yang menggunakan pembelajaran konvensional. Nursyamsi SY (2016) menyatakan dari perbandingan rerata terkoreksi diketahui bahwa strategi pembelajaran NHT memberikan pengaruh lebih besar, yaitu sebesar 21,56\%, dibandingkan pengaruh yang disebabkan oleh pembelajaran konvensional. Mutia Agisni Mulyana (2016) Menyatakan bahwa Model kooperatif tipe Numbered Heads Together (NHT) dapat meningkatkan hasil belajar siswa pada materi kenampakan alam dan sosial budaya. Siti Nuryanti (2014) juga menyatakan penerapan model pembelajaran kooperatif tipe Numbered Head Together dapat meningkatkan hasil belajar IPA siswa Kelas IV SD Negeri 3 Tondo Palu. Sejalan dengan itu penelitian Witari (2017) menyatakan bahwa model pembelajaran NHT berpengaruh terhadap hasil Belajar IPA.

Widodo (2013) menyatakan terkait hasil belajar bahwa dengan menggunakan metode pembelajaran berbasis masalah dapat meningkatkan kegiatan pembelajaran dan hasil belajar siswa. Monawati (2016) juga menyatakan bahwa upaya meningkatkan Hasil Belajar Siswa melalui Lesson Study pada Penjumlahan Pecahan di Kelas IV SDN Lamsayeun. Pukjiwati (2017) menyatakan penelitian pendekatan CTL ini dapat meningkatkan kualitas hasil belajar siswa terhadap mata pelajaran Matematika tentang Operasi Hitung Pecahan dalam Pemecahan Masalah kelas IV SD Negeri Sumur 03, Kecamatan Cluwak, Kabupaten Pati, melalui media belajar dan mengajar.

\section{Simpulan dan Saran}

Berdasarkan hasil penelitian dan pembahasan yang telah dipaparkan, dapat disimpulkan bahwa terdapat pengaruh hasil belajar pada mata pelajaran Matematika antara kelompok siswa yang dibelajarkan menggunakan model pembelajaran kooperatif tipe NHT dan kelompok siswa yang dibelajarkan tidak menggunakan model pembelajaran kooperatif tipe NHT pada siswa kelas V SD di Gugus IV Sukasada Kecamatan Sukasada, Kabupaten Buleleng Tahun Pelajaran 2017/2018. Hal tersebut diperoleh dari hasil penghitungan uji-t, thitung sebesar 3,3, sedangkan, ttabel (dengan $\mathrm{db}=38$ pada taraf signifikansi 5\%) adalah 2,021. Hal ini berarti, thitung lebih besar dari ttabel (thit > ttab), sehingga H0 ditolak dan H $\neg 1$ diterima. Dari rata-rata ( ), diketahui ( ) kelompok eksperimen sebesar 21,1 dan ( ) kelompok kontrol sebesar 18,95. Hal ini berarti ( ) eksperimen > ( ) kontrol. Dengan demikian, model pembelajaran kooperatif tipe NHT berpengaruh terhadap hasil belajar siswa pada mata pelajaran Matematika.

Saran yang dapat disampaikan berdasarkan penelitian yang telah dilakukan adalah sebagai berikut. 1) Seluruh siswa kelas V SD di Gugus IV Sukasada Kecamatan Sukasada, Kabupaten Buleleng agar selalu giat belajar, memperhatikan pelajaran, serta berpartisipasi aktif dalam proses pembelajaran sehingga dapat mencapai hasil belajar yang optimal khususnya pada mata pelajaran Matematika, 2) Dengan diterapkannya model pembelajaran kooperatif tipe NHT pada penelitian ini, hendaknya guru lebih termotivasi dalam menggunakan model-model pembelajaran yang inovatif dalam melaksanakan proses pembelajaran di kelas sehingga dapat meningkatkan kualitas proses dan hasil belajar Matematika siswa, 3) Kepala sekolah agar dapat menjadikan hasil penelitian ini sebagai dasar pengambilan kebijakan untuk membina guru dalam mengembangkan model - model pembelajaran yang lebih inovatif, 4) Peneliti yang berminat untuk mengadakan penelitian lebih lanjut tentang model pembelajaran kooperatif tipe NHT pada pembelajaran Matematika maupun bidang ilmu lainnya yang sesuai agar memerhatikan kendalakendala yang dialami dalam penelitian ini sebagai bahan pertimbangan untuk perbaikan dan penyempurnaan penelitian yang akan dilaksanakan

\section{Daftar Rujukan}

Agung, A. A. Gede. 2010. Evaluasi Pendidikan. Singaraja. Universitas Pendidikan Ganesha

Arikunto, Suharsimi. 2002. Dasar-Dasar Evaluasi Pendidikan. Jakarta: PT Bumi Aksara

Candiasa. 2011. Pengujian Instrumen Penelitian Disertai Aplikasi ITEMAN dan BIGSTEP. Singaraja. Unit Universitas Pendidikan Ganesha

Dewi, Fika. 2016. Pengaruh Model Pembelajaran Kooperatif Tipe Numbered Head Together terhadap Hasil Belajar Siswa Pada Mata Pelajaran Matematika Kelas V SDN 1 Raman Endra.

Koyan, I Wayan. 2012. Statistik Pendidikan Teknik Data Kuantitatif. Singaraja. Universitas Pendidikan Ganesha. 
Kurniasih, Imas \& Berlin Sani. 2015. Ragam Pengembangan Model Pembelajaran Untuk Peningkatan Profesionalitas Guru. Jogjakarta: Kata Pena.

Monawati, M. Yamin. 2016. Upaya Meningkatkan Hasil Belajar Siswa Melalui Lesson Study Pada Penjumlahan Pecahan Di Kelas IV Sdn Lamsayeun. JURNAL PESONA DASAR Universitas Syiah Kuala. Vol. 3 No.4, Oktober.

Muslimin. 2000. Pembelajaran Kooperatif. Surabaya: Unesa University Press.

Mutia Agisni Mulyana, Nurdinah Hanifah, Asep Kurnia Jayadinata. 2016. Penerapan Model Kooperatif Tipe Numbered Heads Together (NHT) Untuk Meningkatkan Hasil Belajar Siswa Pada Materi Kenampakan Alam Dan Sosial Budaya. Jurnal Pena Ilmiah UPI. Vol 1 No 1.

Nursyamsi SY, Aloysius Duran Corebima, Herawati Susilo. 2016. Pengaruh Strategi Pembelajaran Numbered Heads Together (NHT) terhadap Hasil Belajar Siswa SMA Negeri 1 Muara Badak. Jurnal Pendidikan: Teori, Penelitian, dan Pengembangan. Vol 1 No 10 Edisi Oktober.

Punaji, H. 2012. Metode Penelitian Pendidikan dan Pengembangan. Jakarta: Kencana

Pukjiwati. 2017. Upaya Meningkatkan Aktivitas Hasil Belajar Siswa Pada Materi Pecahan Dengan Pendekatan Contextual Teaching and Learning Kelas IV SDN Sumur 03. JURNAL REFLEKSI EDUKATIKA Universitas Muria Kudus. Volume 7 (2).

Ridwanthi, Kd Dian Prima, I Gst. N. Japa, A. A Gede Agung. 2013. Pengaruh Model Pembelajaran Kooperatif Tipe Nht Berbantuan Media Question Cards Terhadap Hasil Belajar Matematika Siswa Kelas Iv Sdn 6 Bondalem. Mimbar PGSD Undiksha Vol 1 No 1.

Rika Fima Yenni. 2016. Penggunaan Metode Numbered Head Together (NHT) Dalam Pembelajaran Matematika. Jurnal Penelitian dan Pembelajaran Matematika. Jurnal Penelitian dan Pembelajaran Matematika. Vol 9 No 2.

Sadirman, A. M. 2011. Interaksi Dan Motivasi Belajar-Mengajar. Jakarta: Rajawali Pers.

Siti Nuryanti. 2014. Penerapan Model Pembelajaran Kooperatif Tipe Numbered Head Together (Nht) Untuk Meningkatkan Hasil Belajar Siswa Pada Mata Pelajaran Ipa Kelas IV Sd Negeri 3 Tondo. Jurnal Diknas. Volume 2 No 2.

Suriani, Kt., I Nym. Murda, Ni Wy. Arini. 2013. Pengaruh Model Pembelajaran Kooperatif Tipe Nht Berbantuan Media Flip Chart Terhadap Hasil Belajar Ipa Siswa Kelas V SD. Mimbar PGSD Undiksha Vol 1 No 1.

Trianto. 2009. Mendesain Model Pembelajaran Inovatif-Progresif-Konsep, Landasan, dan Implementasinya Pada Kurikulum Tingkat Satuan Pendidikan (KTSP). Jakarta : Kencana.

Wati, Ni Nym. Kurnia, I G. N. Japa, A. A. Gede Agung. 2013. Pengaruh Model Pembelajaran Kooperatif Tipe Numbered Head Together Bermuatan Media Cerita Ramayana Terhadap Hasil Belajar Pkn Di Sd No 3 Banjar Jawa Mimbar PGSD Undiksha Vol 1 No 1.

Widodo, Lusi Widayanti. 2013. Peningkatan Aktivitas Belajar Dan Hasil Belajar Siswa Dengan Metode Problem Based Learning Pada Siswa Kelas Viia Mts Negeri Donomulyo Kulon Progo. Jurnal Fisika Indonesia No: 49, Vol XVII, Edisi April.

Witari, I Gusti Ayu. 2017. Pengaruh Model Pembelajaran Kooperatif Tipe Numbered Head Together (NHT) Terhadap hasil Belajar IPA Siswa Kela IV di SDN Gugus I Kecamatan sawan Tahun Pelalajaran 201/2017. Jurnal MImbar PGSD Universitas Pendidikan Ganesha Volume 3 Nmor 4. 